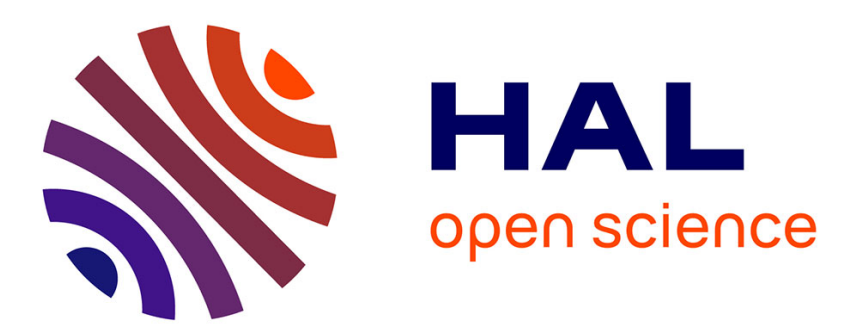

\title{
Polyamine derivatives: a revival of an old neglected scaffold to fight resistant Gram-negative bacteria?
}

\author{
Marine Blanchet, Diane Borselli, Jean Michel Brunel
}

\section{To cite this version:}

Marine Blanchet, Diane Borselli, Jean Michel Brunel. Polyamine derivatives: a revival of an old neglected scaffold to fight resistant Gram-negative bacteria?. Future Medicinal Chemistry, 2016, 8, pp.963 - 973. 10.4155/fmc-2016-0011 . hal-01420812

\section{HAL Id: hal-01420812 \\ https://hal.science/hal-01420812}

Submitted on 21 Dec 2016

HAL is a multi-disciplinary open access archive for the deposit and dissemination of scientific research documents, whether they are published or not. The documents may come from teaching and research institutions in France or abroad, or from public or private research centers.
L'archive ouverte pluridisciplinaire HAL, est destinée au dépôt et à la diffusion de documents scientifiques de niveau recherche, publiés ou non, émanant des établissements d'enseignement et de recherche français ou étrangers, des laboratoires publics ou privés. 


\title{
Polyamine derivatives: a revival of an old neglected scaffold to fight resistant Gram-
} negative bacteria?

\section{Marine Blanchet ${ }^{1}$, Diane Borselli ${ }^{2}$ and Jean Michel Brunel ${ }^{* 1}$}

${ }^{1}$ Centre de Recherche en Cancérologie de Marseille (CRCM), CNRS, UMR7258; Institut Paoli Calmettes; Aix-Marseille Université, UM 105; Inserm, U1068, F-13009, Marseille, France.

2 UMR-MD1, Aix-Marseille Université, IRBA, TMCD2, 27 Bd Jean Moulin, 13385 Marseille, France.

(*) Corresponding author:

Brunel, Jean Michel, CRCM, UMR 7258 CNRS, Aix Marseille Université, Faculté de Pharmacie, 27 Bd Jean Moulin, 13385 Marseille cedex 05

e-mail : bruneljm@yahoo.fr $\quad$ Tel : 33689271645

\begin{abstract}
Emergence of multidrug resistant pathogens was responsible for microbial infections and inefficacy of numerous antimicrobial therapies has induced a need for the research of new classes of antibiotics. In this review, we will focus our interest towards the biological properties of polyamino antimicrobial agents.
\end{abstract}

Keywords: Gram-negative bacteria - Multidrug resistance - Antibiotic enhancers Polyamines - Antimicrobial agents 
Each year in the United States, at least 2 million people become infected with bacteria that are resistant to antibiotics and at least 23.000 people die annually as a direct result of these infections. The introduction in the Mid- $20^{\text {th }}$ century of efficient antibiotic therapies for infectious diseases has completely modified clinical practices in the development of lifethreatening conditions leading to reduce the incidence of death resulting from bacterial infections. However, the rise of antibiotic resistance since few decades has resulted in a very pressing need for the discovery of novel antibiotics or treatment strategies [1]. In this context, numerous active avenues of research on-going to develop the next generation of antibacterial drugs are under current investigations such as the combination of two active antibacterial agents into one hybrid compound or synthetic peptide mimics [2].

Some strains have become resistant to practically all of the commonly available agents. A notorious case is the methicillin-resistant Staphylococcus aureus (MRSA), which is resistant not only to methicillin but usually also to aminoglycosides, macrolides and cyclines. Such strains are also resistant to disinfectants, and can act as a major source of hospital-acquired infections. An even more serious threat may be the emergence of Multidrug resistant (MDR) Gram-negative pathogens that are a global public health concern as therapeutic options for treating such infections are dwindling. Thus, Multidrug resistance in bacteria occurs by the presence of plasmids or transposons, of genes, with each coding for resistance to a specific agent, and/or by the action of multidrug efflux pumps, each of which can pump out more than one drug type.

Furthermore, the emergence of "pan-resistant" Gram-negative strains, notably those belonging to Pseudomonas aeruginosa and Acinetobacter baumannii, occurred more recently, after most major pharmaceutical companies stopped the development of new antibacterial agents. Hence, there are almost no agents that could be used against these strains, in which an 
outer membrane barrier of low permeability is combined with multitudes of specific resistance mechanisms.

On the basis of such observations, there is a need for the development of new strategies and a revival for the use of neglected polyamino derivatives has emerged as antimicrobial agents able to fight resistant Gram-negative bacteria. Polyamines are small aliphatic hydrocarbon molecules with quaternary nitrogen groups that have a net positive charge at physiological $\mathrm{pH}$. During the 60's and 70's polyaminated molecules were identified in all forms of life such as bacteria, fungi, plants and all types of eukaryotic cells. They were described to be critical for all types of cellular proliferation by determining the metabolic pathways of synthesis and degradation. Thus the apparent critical influence of polyamines on cell development and survival and their recognition by the polyamine transporters have both led to polyamines being increasingly considered for the design of a range of chemotherapeutic agents [3].

On the other hand, it has been widely demonstrated that polyamines can act as endogenous modulators of outer membrane permeability [4] of bacteria inducing resistance to cationic peptide, aminoglycoside or quinolone antibiotics [5].

Polyamines are old polycationic molecules widely distributed in nature described for very first time in 1677 in seminal fluid [6]. It has been widely demonstrated that some of them such as cadaverine [7] or spermine [4] could decrease bacteria outer membrane permeability by being natural regulators of porin activity and subsequently reduce bacterial susceptibility to antibiotic treatments [8-10].

Surprisingly, it has been found that polyamines at millimolar levels can increase the susceptibility of $P$. aeruginosa to a variety of antibiotics (Table 1) [11] whereas Vaara et al. by using submillimolar concentrations have observed a discrepant outcome [12]. It has appeared that polyamines might be potentially useful in antipseudomonal therapies by increasing the effectiveness of numerous $\beta$-lactam antibiotics. 
Table 1. MICs of antibiotics to P. aeruginosa PAO1 in the presence of polyamines

\begin{tabular}{cccccc}
\hline \multicolumn{5}{c}{ MIC $(\mu \mathrm{g} / \mathrm{mL})$ in presence of } \\
\hline Antibiotic & No & Spd & Spn & Put & Cad \\
\hline Ampicilline & $>1024$ & 64 & 64 & 128 & 128 \\
Aztreonam & 4 & 0.5 & 0.5 & 1 & 0.5 \\
Ceftazidine & 2 & 0.5 & 0.5 & 1 & 0.5 \\
Chloramphenicol & 128 & 32 & 32 & 64 & 64 \\
Nalidixic acid & 128 & 64 & 64 & 64 & 64 \\
Erythromycine & 128 & 128 & 64 & 128 & 128 \\
\hline
\end{tabular}

Compound concentrations were as follows: $20 \mathrm{mM}$ spermidine (Spd), putrescine (Put), cadaverine (Cad); $1 \mathrm{mM}$ spermine (Spn).

Thus, these results suggested the development of a new approach involving polyamino derivatives as potent either antimicrobial agents or chemosensitizers of ineffective antibiotics against MDR bacteria.

\section{Development of new polyamino antimicrobial agents}

Different polyamino antimicrobial agents have been designed and we can classify these derivatives according two major classes belonging to a steroidal or a non-steroidal family.

\section{Non-steroidal derivatives}

In 1998, Cook et al. have prepared a 1638-member meta-substituted benzyl pyridinopolyamine library by solution-phase chemistry. Twelve compounds 1-12 exhibit potent, highly selective activity against Gram-positive bacteria over Gram-negative bacteria and very high specificity for bacteria compared with the fungus $C$. albicans. Thus, $S$. pyogenes, S. aureus, and E. faecalis were inhibited at MICs of 1-12 $\mu \mathrm{M}$, whereas MICs for $E$. coli, $K$. pneumoniae, $P$. vulgaris, and $P$. aeruginosa were $>100 \mu \mathrm{M}$. It clearly appeared that 
functional groups in the meta-positions of the benzyl functionality set do indeed provide sufficient differentiating diversity to allow biological activities to be separated and identified from a library by iterative and positional scanning deconvolution processes (Table 2) [13].

Table 2. Structures and antimicrobial activities of meta-substituted benzyl pyridinopolyamine derivatives 1-12.

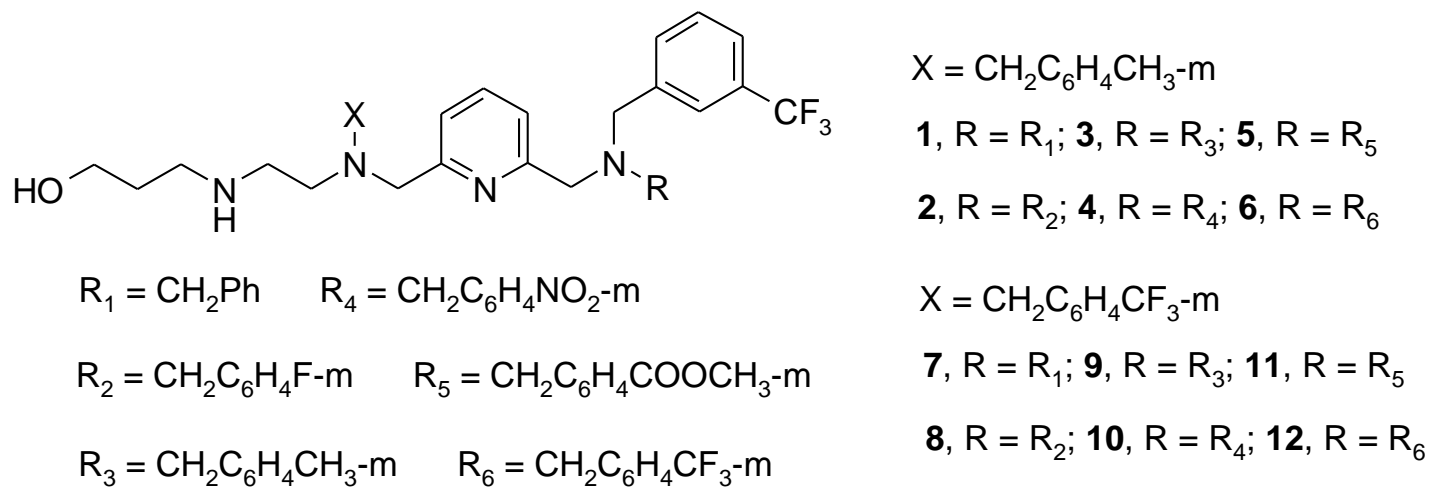

$\operatorname{MIC}(\mu \mathrm{g} / \mathrm{mL})$

\begin{tabular}{ccccccccc}
\hline Cpd & $S$. & $E$. & $E$. & $S$. & $P$. & $P$. & $K$. & $C$. \\
& aureus & faecalis & coli & pyogenes & aeruginosa & vulgaris & pneumoniae & albicans \\
\hline $\mathbf{1}$ & $3-6$ & $3-6$ & $12-25$ & $1-5$ & $>100$ & $>100$ & $6-12$ & $<12.5$ \\
$\mathbf{2}$ & $3-6$ & $3-6$ & $>100$ & $1-5$ & $>100$ & $>100$ & $12-25$ & $<12.5$ \\
$\mathbf{3}$ & $3-6$ & $3-6$ & $>100$ & $1-5$ & $>100$ & $>100$ & $6-12$ & $<12.5$ \\
$\mathbf{4}$ & $3-6$ & $3-6$ & $>100$ & $1-5$ & $>100$ & $>100$ & $>100$ & 25 \\
$\mathbf{5}$ & $6-12$ & $3-6$ & $>100$ & $1-5$ & $>100$ & $>100$ & $>100$ & $<12.5$ \\
$\mathbf{6}$ & $6-12$ & $3-6$ & $>100$ & $1-5$ & $>100$ & $>100$ & $>100$ & $>100$ \\
$\mathbf{7}$ & $12-25$ & $6-12$ & $>100$ & $1-5$ & $>100$ & $>100$ & $25-50$ & $>100$ \\
$\mathbf{8}$ & $6-12$ & $3-6$ & $>100$ & $3-6$ & $>100$ & $>100$ & $>100$ & $>100$ \\
$\mathbf{9}$ & $6-12$ & $3-6$ & $>100$ & $1-3$ & $>100$ & $>100$ & $50-100$ & $>100$ \\
$\mathbf{1 0}$ & $3-6$ & $3-6$ & $>100$ & $1-3$ & $>100$ & $>100$ & $>100$ & $>100$ \\
$\mathbf{1 1}$ & $6-12$ & $3-6$ & $>100$ & $1-3$ & $>100$ & $>100$ & $>100$ & $>100$
\end{tabular}


On the other hand, a series of chloramphenicol (CAM) amides with polyamines 13-17 were recently synthesized either by direct attachment of the PA chain on the 2-aminopropane-1,3diol backbone of CAM, previously oxidized selectively at its primary hydroxyl group, or from chloramphenicol base (CLB) through acylation with succinic or phthalic anhydride and finally coupling with a PA. In this context, conjugates 16 and 17 possessing a dibenzylated spermidine moiety through the succinate linker were the most potent antibacterial agents against Gram-positive (S. aureus) and Gram-negative (E. coli) bacterial strains (Table 3) [14]. Table 3. Determination of $\mathrm{IC}_{50}$ for chloramphenicol and its polyamino parent derivatives against wild-type and mutant $S$. aureus and E. coli.<smiles>[R]N([R])C(=O)CCC(=O)N[C@@H](CO)[C@H](O)c1ccc([N+](=O)[O-])cc1</smiles>

$$
\begin{aligned}
& \text { 13: } \mathrm{R}_{1}=\mathrm{H}, \mathrm{R}_{2}=\left(\mathrm{CH}_{2}\right)_{4} \mathrm{NH}_{2} \\
& \text { 14: } \mathrm{R}_{1}=\mathrm{H}, \mathrm{R}_{2}=\left(\mathrm{CH}_{2}\right)_{3} \mathrm{NH}\left(\mathrm{CH}_{2}\right)_{4} \mathrm{NH}\left(\mathrm{CH}_{2}\right)_{3} \mathrm{NH}_{2} \\
& \text { 15: } \mathrm{R}_{1}=\left(\mathrm{CH}_{2}\right)_{3} \mathrm{NH}_{2}, \mathrm{R}_{2}=\left(\mathrm{CH}_{2}\right)_{4} \mathrm{NH}_{2} \\
& \text { 16: } \mathrm{R}_{1}=\left(\mathrm{CH}_{2}\right)_{3} \mathrm{NH}_{2}, \mathrm{R}_{2}=\left(\mathrm{CH}_{2}\right)_{4} \mathrm{~N}\left(\mathrm{CH}_{2} \mathrm{Ph}\right)_{2} \\
& \text { 17: } \mathrm{R}_{1}=\mathrm{H}, \mathrm{R}_{2}=\left(\mathrm{CH}_{2}\right)_{3} \mathrm{NH}\left(\mathrm{CH}_{2}\right)_{4} \mathrm{~N}\left(\mathrm{CH}_{2} \mathrm{Ph}\right)_{2}
\end{aligned}
$$

\begin{tabular}{cccccc}
\hline \multicolumn{5}{c}{$\mathrm{IC}_{50}(\mu \mathrm{M})$} \\
\hline Cpd & $\begin{array}{c}\text { MRSA } \\
(\mathrm{GRE2272})\end{array}$ & $\begin{array}{c}\text { S. aureus } \\
(\mathrm{WT})\end{array}$ & $\begin{array}{c}\text { E. coli } \\
(\mathrm{A} 2058 \mathrm{G})\end{array}$ & $\begin{array}{c}\text { E. coli } \\
(\mathrm{WT})\end{array}$ & $\begin{array}{c}\text { E. coli } \\
(\Delta \mathrm{tolC})\end{array}$ \\
\hline CAM & 8.0 & 3.1 & 15.5 & 6.2 & 2.0 \\
$\mathbf{1 3}$ & $>200$ & $>200$ & $>200$ & $>200$ & $>200$ \\
$\mathbf{1 4}$ & $>200$ & 45.3 & $>100$ & $>100$ & $>100$ \\
$\mathbf{1 5}$ & $>100$ & 12.7 & $>150$ & $>150$ & $>100$ \\
$\mathbf{1 6}$ & 7 & 4.7 & 9.4 & 9.4 & 19.0 \\
& $>100$ & 13.7 & 32.3 & 35.5 & 42.5 \\
\hline
\end{tabular}


Among infectious diseases, tuberculosis still remains one of the leading single agent killer in the world with aound 2 million of deaths each year. Polyamino derivatives N-geranyl-N'-(2adamantyl)ethane-1,2-diamine SQ109 18 (Figure 1), a second generation agent from the first line drug ethambutol demonstrated interesting activities against both M. tuberculosis and $M$. smegmatis with MICs of 0.5 and $2 \mu \mathrm{g} / \mathrm{mL}$, respectively [15].

Figure 1. Structure of derivative SQ109 18

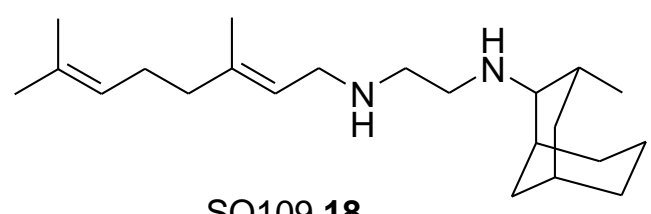

Nevertheless, the bioavailability of this product remains low limiting its development and therapeutical use [16].

In 2010, Wu et al. isolated from the bacterial pathogen Dickeya Zeae strain DZ1 a new antibacterial compound namely zeamine 19. Of peculiar note is that numerous MDR bacteria such as $P$. aeruginosa and $B$. cenocepacia are susceptible to zeamine with excellent to moderate MIC values varying from 0.3 to $50 \mu \mathrm{g} / \mathrm{mL}$ depending on the nature of the considered bacterial strain (Table 4) [17].

Table 4. Structure and antimicrobial activities of zeamine $\mathbf{1 9}$

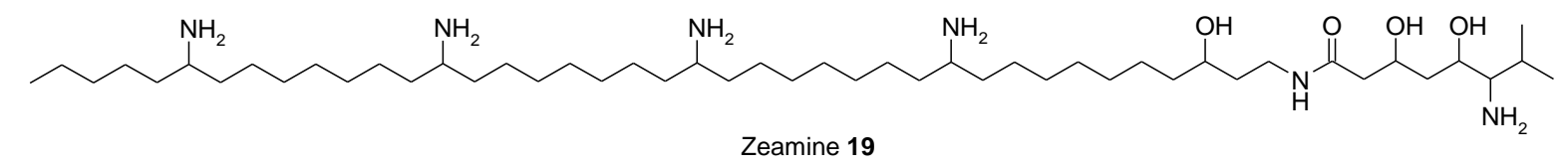

$\operatorname{MIC}(\mu \mathrm{g} / \mathrm{mL})$

\begin{tabular}{cccccccc}
\hline \multirow{2}{*}{ Strain } & S. Aureus & B. Cereus & E. Coli & B. Cepacia & P.Aeruginosa & S. & K. \\
& ATCC25531 & XJ8 & CFT073 & H111 & PAO1 & enterica & pneumoniae \\
\hline $\mathbf{1 9}$ & 0.3 & 3 & 3 & 50 & 5 & 3 & 6 \\
\hline
\end{tabular}


Finally, homologous series of mono- and bis-acyl polyamines 20-32 with varying acyl chain lengths were also designed and presented moderate MICs against Gram-positive (S. aureus) and Gram-negative (E. coli) bacterial strains (Table 5) [18].

Table 5. Structure and antimicrobial activities of mono- and bis-acyl polyamines 20-32
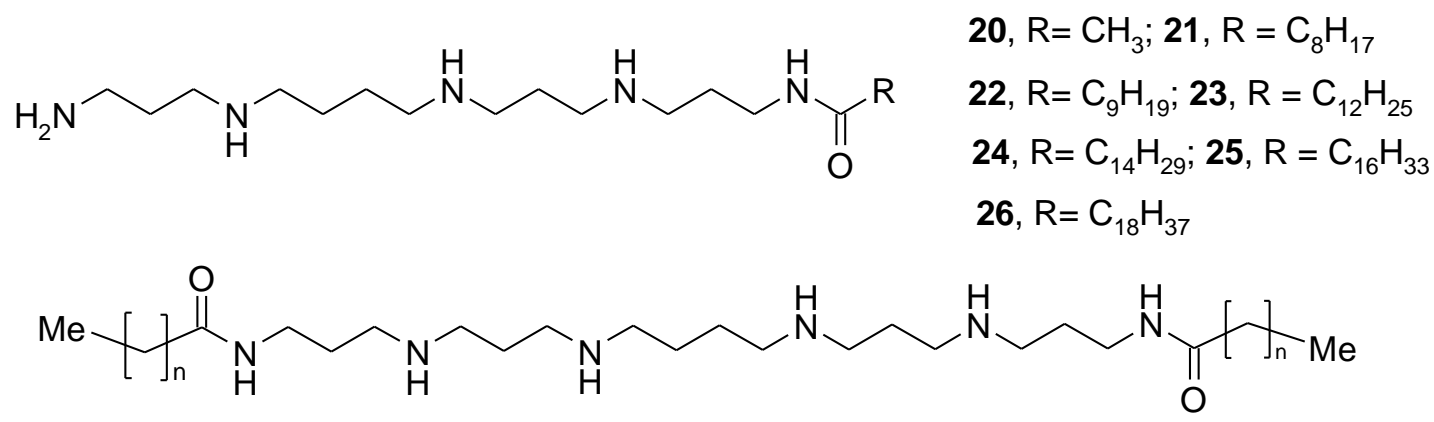

$27, \mathrm{n}=7 ; 28, \mathrm{n}=8 ; 29, \mathrm{n}=10$;

$30, \mathrm{n}=13 ; 31, \mathrm{n}=15 ; 32, \mathrm{n}=17$

\begin{tabular}{ccc||ccc}
\hline \multicolumn{5}{c}{ MIC $(\mu \mathrm{M})$} \\
\hline Cpd & $\begin{array}{c}\text { S. aureus } \\
(\mathrm{WT})\end{array}$ & $\begin{array}{c}\text { E. coli } \\
(\mathrm{A} 2058 \mathrm{G})\end{array}$ & Cpd & $\begin{array}{c}\text { S. aureus } \\
(\mathrm{WT})\end{array}$ & $\begin{array}{c}\text { E. coli } \\
(\mathrm{A} 2058 \mathrm{G})\end{array}$ \\
\hline $\mathbf{2 0}$ & 250 & 62.5 & $\mathbf{2 7}$ & 15.6 & 31.25 \\
$\mathbf{2 1}$ & 125 & 62.5 & $\mathbf{2 8}$ & 3.9 & 31.25 \\
$\mathbf{2 2}$ & 62.5 & 62.5 & $\mathbf{2 9}$ & 15.6 & 31.25 \\
$\mathbf{2 3}$ & 15.6 & 31.25 & $\mathbf{3 0}$ & 250 & 62.5 \\
$\mathbf{2 5}$ & 15.6 & 31.25 & $\mathbf{3 1}$ & 250 & 62.5 \\
$\mathbf{2 6}$ & 15.6 & 62.5 & $\mathbf{3 2}$ & 125 & 62.5 \\
\hline
\end{tabular}

\section{Steroidal derivatives}

On the other hand, numerous compounds possessing a sterol core were identified to possess interesting antibacterial activities. Among them, Squalamine 33, a natural polyaminosterol derivative isolated from the shark Squalus acanthias was reported to be active against a large 
panel of microorganisms with MICs ranging from 1 to $8 \mu \mathrm{g} / \mathrm{mL}$ against Gram positive and Gram-negative bacteria (Table 6) [19].

Table 6. Antibacterial activities of squalamine 33 (MICs mg/L).

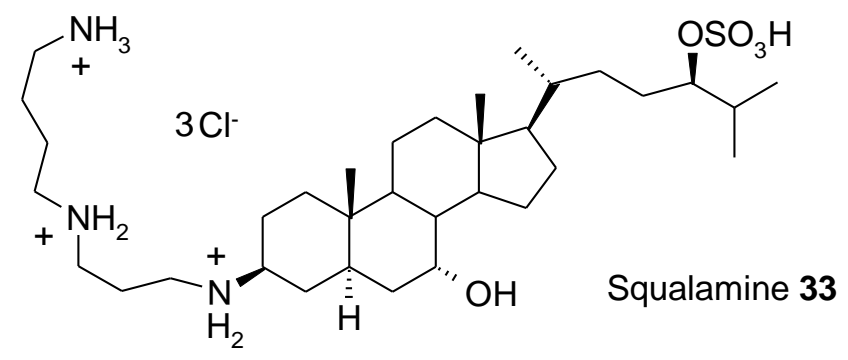

\begin{tabular}{cccc|cccc}
\hline & \multicolumn{3}{c|}{ Gram positive bacteria } & \multicolumn{4}{c}{ Gram negative bacteria } \\
\cline { 2 - 7 } Cpd & $\begin{array}{c}S . \\
\text { aureus }\end{array}$ & $\begin{array}{c}\text { Sneumoniae } \\
\text { pnecalis }\end{array}$ & faeli & aeruginosa & pneumoniae & aerogenes \\
\hline 33 & $2-8$ & 32 & - & 8 & $2-8$ & 8 & 32 \\
\hline
\end{tabular}

On the basis of such results, the synthesis of numerous derivatives 34-37 from stigmasterol was achieved by Shu et al. (Figure 2) demonstrating that $3 \beta$ analogs exhibit better activity than $3 \alpha$ ones [20]. From his part, Selinsky et al. reported that squalamine analogues 38-41 differing in the identity of the polyamine attached at C3 of the sterol, and the stereochemistry of a hydroxyl substituent at C7 possessed different antimicrobial activities [21]. Thus, analogs with a tetraammonium spermine polyamine appear to be somewhat more active than analogs with a shorter trisammonium spermidine polyamine, and analogs with an axial $(\alpha)$ hydroxyl substituent at $\mathrm{C} 7$ are more active than analogs with the corresponding equatorial $(\beta)$ hydroxyl one. Otherwise, $7 \beta-\mathrm{OH}$ spermine analog is the most active compound against $E$. coli, but the least effective against $P$. aeruginosa (MICs varying from 1 to $32 \mu \mathrm{g} / \mathrm{mL}$, respectively).

On the other hand, Khan et al. reported the synthesis of a series of $3 \beta$-hydroxy- $7 \alpha$-amino 23,24-bisnor-5 $\alpha$-cholan-22-ol derivatives such as compound 42 which demonstrates a good 
activity against Gram positive bacteria (MICs values $1.6-25 \mu \mathrm{g} / \mathrm{mL}$ ) with respect to Gram negative ones (MICs value 6.3 to $>100 \mu \mathrm{g} / \mathrm{mL}$ ) [22], [23]. Similar results were encountered by Kim et al. by using 3-polyamino-23,24-bisnorcholane derivatives [24].

Figure 2. Structures of polyaminosterol derivatives 34-42

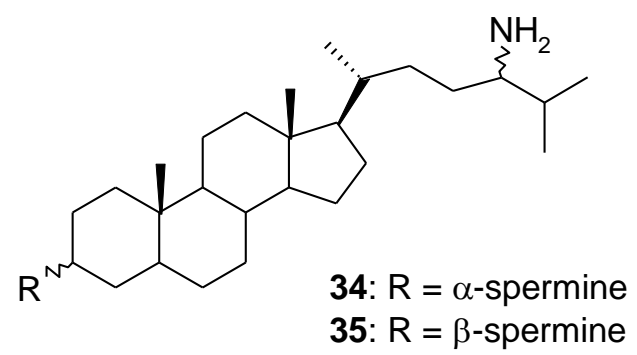

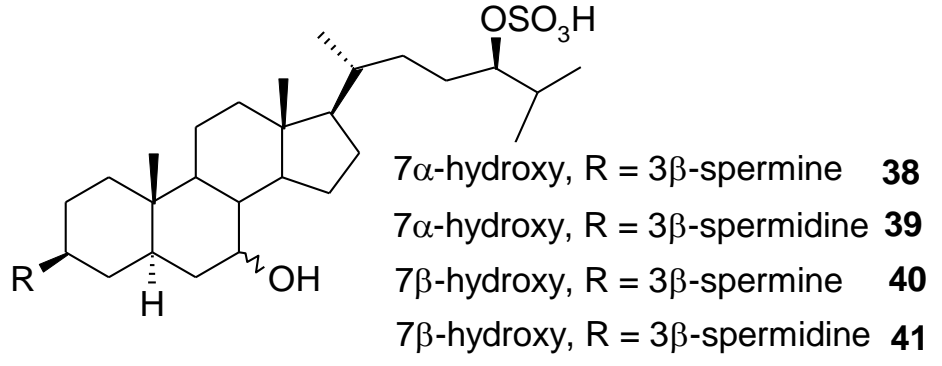<smiles>[R7]C1CCC2(C)C(CCC3C2CCC2(C)C3CCC2[C@@H](C)CC[C@H](O)C(C)C)C1</smiles>
37: $R=\beta$-spermine

Amino deoxycholic acid derivatives were also reported to be active against numerous bacteria and even against vancomycin and methicillin resistant strains suggesting a high correlation between the cationic charge of the polyamine chain group and the biological activity [25]. Recently, numerous 3 and 7-polyaminosterol squalamine analogues such as 43-44 (Figure 3) were synthesized and demonstrated good activities against both Gram-positive and Gramnegative bacterial strains with MICs varying from 2.5 to $10 \mu \mathrm{g} / \mathrm{mL}$ [26][27] even against multi drug resistant strains recovered from cystic fibrosis patients (137 strains) [28].

Figure 3. Structure of 7-polyaminosterol derivatives 43-44.

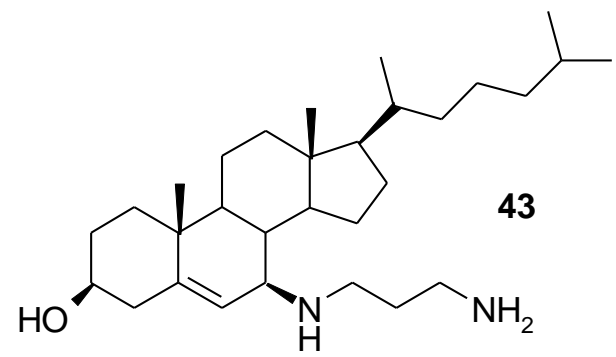<smiles>CC(C)CCCC(C)[C@H]1CCC2C3C(NCCCN)CC4C[C@@H](O)CC[C@]4(C)C3CC[C@]21C</smiles> 
In the case of Gram positive bacteria, Alhanout et al. demonstrated that the activity of squalamine or its parent derivatives is due to a strong depolarization of the membrane with drained cytoplasmic content suggesting a "detergent like" mechanism [29]. On the opposite, in the case of Gram-negative bacteria these derivatives are able to disturb the membrane integrity of Gram negative bacteria by interaction with negative charges of phosphate groups of the LPS at the surface of the outer membrane [30].

On the basis of such a mechanism, 3,20-Amino- and polyaminosteroid analogs of squalamine such as derivative $\mathbf{4 5}$ were synthesized and evaluated for their in vitro antimicrobial properties against reference and clinical bacterial strains exhibiting MICs ranging from 2.5 to $40 \mu \mathrm{g} / \mathrm{mL}$ (Table 7) [31].

Table 7. Antibacterial activities of the 3,20-polyaminosterol derivative 45 (MICs $\mu \mathrm{g} / \mathrm{mL}$ ).

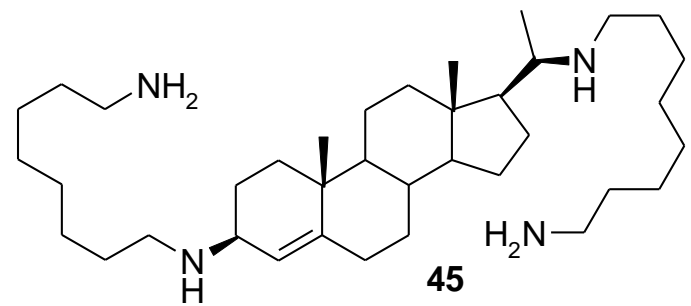

\begin{tabular}{cccccc}
\hline \multicolumn{6}{c}{ Minimum Inhibition Concentration (MIC $(\mu \mathrm{g} / \mathrm{mL}))$} \\
\hline Compound & S. aureus & E. coli & P.aeruginosa & I. limosus & B. cepacia \\
& & & & & \\
\hline $\mathbf{4 5}$ & 2.5 & 5 & 2.5 & $10-20$ & $>40$ \\
\hline
\end{tabular}

\section{Development of polyamino chemosensitizers for antibiotic activity enhancement}

One of the first studies was realized by Yasuda et al. in 2004 dealing with the synthesis and use of naphtylacetylspermine $\mathbf{4 6}$ and methoctramine $\mathbf{4 7}$ as chemosensitizer agents increasing E. coli membrane permeability. No intrinsic antimicrobial properties were encountered for these compounds but they are able to highly potentiate novobiocine or erythromycin antimicrobial activities (Table 8). It has been suggested that these compounds could alter 
membrane integrity by displacing divalent cations leading to an enhancement of noviobiocine and eryhtromycine entrance [32].

Table 8. Chemical structure of naphtylacetylspermine $\mathbf{4 6}$ and methoctramine $\mathbf{4 7}$ and their use as chemosensitizers against $E$. coli
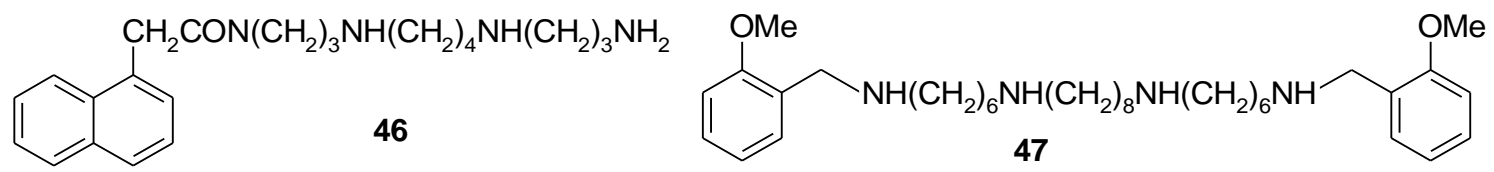

\section{$\operatorname{MIC}(\mu \mathrm{g} / \mathrm{mL})$}

\section{Antibiotic}

Used concentrations $(\mu \mathrm{g} / \mathrm{mL})$ of polyamines 46 and 47

\begin{tabular}{|c|c|c|c|c|c|c|c|c|c|c|c|c|}
\hline & & \multicolumn{7}{|c|}{ Naphtylacetylspermine 46} & \multicolumn{4}{|c|}{ Méthoctramine 47} \\
\hline & & 2 & 4 & 8 & 16 & 32 & 64 & 128 & 1 & 2 & & 8 \\
\hline Novobiocine & 128 & $128 \quad 64$ & 32 & 16 & 8 & 4 & 1 & 0.5 & 128 & 128 & & 16 \\
\hline Erythromycine & 64 & 64 & 64 & 31 & 16 & 8 & 4 & 4 & 64 & 64 & & 16 \\
\hline
\end{tabular}

Otherwise, due to its previously described properties, an approach using squalamine as a chemosensitizer agent has been envisioned against resistant strains by using it at 1/5 and 1/10 of its MIC value to enhance significantly the activity of numerous antibiotics against isogenic multidrug E. coli AG100 and AG100Atet strains (Table 9) [33].

Table 9. Effect of sub-inhibitory concentrations of squalamine $\mathbf{3 3}$ on the antibiotic susceptibility of various Gram-negative bacteria 


\begin{tabular}{|c|c|c|c|c|c|c|}
\hline & & \multicolumn{5}{|c|}{ MIC $(\mu \mathrm{g} / \mathrm{mL})$} \\
\hline Bacteria / Strains & Addition & CHL & CIP & TET & FEP & ERY \\
\hline \multirow{3}{*}{ E. coli AG100 } & 0 & 8 & 0.25 & 2 & 0.5 & 512 \\
\hline & $+1 / 5 \mathrm{Sq}$ & 0.5 & 0.03 & 0.125 & 0.06 & 256 \\
\hline & $+1 / 10 \mathrm{Sq}$ & 1 & 0.015 & 0.25 & 0.12 & 256 \\
\hline \multirow{3}{*}{ E. coli AG100A } & 0 & 2 & 0.06 & 2 & 0.5 & 128 \\
\hline & $+1 / 5 \mathrm{Sq}$ & 1 & 0.06 & 0.12 & 0.12 & 64 \\
\hline & $+1 / 10 \mathrm{Sq}$ & 2 & 0.03 & 0.12 & 0.12 & 64 \\
\hline \multirow{3}{*}{$\begin{array}{l}\text { E. coli AG100tet } \\
\text { (acrAB-, over- } \\
\text { producing other } \\
\text { pumps) }\end{array}$} & 0 & 16 & 1 & 64 & 1 & 256 \\
\hline & $+1 / 5 \mathrm{Sq}$ & 2 & 0.03 & 8 & 0.12 & 256 \\
\hline & $+1 / 10 \mathrm{Sq}$ & 4 & 0.03 & 16 & 0.25 & 128 \\
\hline
\end{tabular}

Sq, squalamine 33 was used at 1/10 and 1/5 of its MIC determined for each strain. CHL, chloramphenicol; CIP, ciprofloxacin; TET, tetracycline; FEP, cefepime, ERY, erythromycin.

Such a result appears to be of great interest for the development of new drug combinations against MDR bacteria. Due to all of these considerations, LPS assembly became recently an interesting target due to the fact that its disruption could enhance the entrance of antibiotics through Gram-negative outer membranes. Thus, geraniol, a natural monoterpene encountered in many plant extracts, was demonstrated to act in a synergistic manner with several antibiotics against Gram-negative bacterial species. Numerous geraniol derivatives including geranylamine and polyaminogeranic acid molecules 48-50 were prepared and successfully investigated as chemosensitizers of chloramphenicol and nalidixic acid against Enterobacter and Salmonella strains (Table 10). It has been also demonstrated that they can alter the activity of a drug transporter and inhibit the major Enterobacteriaceae efflux pump, AcrABTolC [34]. 
Table 10: Decrease of chloramphenicol and nalidixic acid resistance in the presence of compounds 48-50.

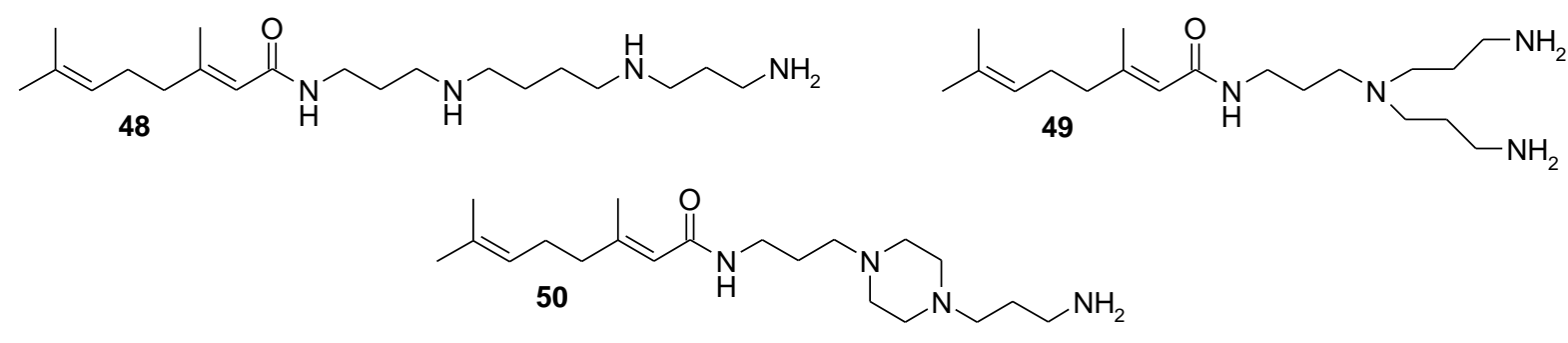

\begin{tabular}{cccc||ccc}
\hline \multicolumn{4}{c||}{ Enterobacter } & \multicolumn{3}{c}{ Salmonella } \\
\hline Cpd & Concentration & \multicolumn{2}{c||}{ MIC ratio } & Concentration & \multicolumn{2}{c}{ MIC ratio } \\
& $(\mu \mathrm{M})$ & $\mathrm{CHL}(*)$ & $\mathrm{NAL}(*)$ & $(\mu \mathrm{M})$ & $\mathrm{CHL}(*)$ & $\mathrm{NAL}(*)$ \\
\hline PAßN & 38 & 16 & 8 & 38 & 8 & 64 \\
$\mathbf{4 8}$ & 31 & 16 & 4 & 31 & 8 & 32 \\
$\mathbf{4 9}$ & 62.5 & 8 & $8-16$ & 125 & 16 & 64 \\
$\mathbf{5 0}$ & 250 & 8 & 4 & 250 & 8 & 64 \\
\hline
\end{tabular}

(*) MIC ratio is determined as the MIC of the antibiotic alone for each strain (ie chloramphenicol or nalidixic acid) to the MIC of the same antibiotic in the presence of compounds 48-50. A ratio up to 1 indicates an improvement of the activity of the antibiotic in the presence of the considered compound.

In this context, another original chemical strategy was developed to prepare non cytotoxic ianthelliformisamine derivatives $\mathbf{5 1 - 5 6}$ which dramatically affected the antibiotic susceptibility of E. aerogenes, P. aeruginosa, and K. pneumoniae MDR strains (Table 11) [35].

Table 11. Concentration of Ianthelliformisamine derivatives 51-56 necessary to restore doxycycline activity $(2 \mu \mathrm{g} / \mathrm{mL})$ against Ea289, PAO1 and KPC2 ST258 Gram-negative bacterial strains. 
<smiles>COc1c(Br)cc(/C=C/C(=O)NCCC[NH2+]CCC[NH3+])cc1Br</smiles><smiles>[CH2][CH2+]NCCCNCCCCNC(=O)/C=C/c1cc(Br)c(OC)c(Br)c1</smiles><smiles>COc1c(Br)cc(/C=C/C(=O)NCCNCCNCCNCCN)cc1Br</smiles><smiles>COc1c(Br)cc(/C=C/C(=O)NCCCNCCCNCCCNC(=O)/C=C/c2cc(Br)c(OC)c(Br)c2)cc1Br</smiles>

lanthelliformisamine C 52<smiles>COc1c(Br)cc(/C=C/C(=O)NCCCN(C)CCCN)cc1Br</smiles><smiles>COc1c(Br)cc(/C=C/C(=O)NCCCN(CCCN)CCCN)cc1Br</smiles>

\begin{tabular}{cccc}
\hline \multirow{2}{*}{ Compounds } & \multicolumn{3}{l}{ Concentration of Ianthelliformisamine derivative used $(\mu \mathrm{M})$} \\
\cline { 2 - 4 } & Ea289 & PAO1 & KPC2 ST258 \\
\hline $\mathbf{5 1}$ & 12.5 & 12.5 & 3.12 \\
$\mathbf{5 2}$ & 6.25 & 3.12 & 12.5 \\
$\mathbf{5 3}$ & 12.5 & 3.12 & 3.12 \\
$\mathbf{5 4}$ & 12.5 & 6.25 & 3.12 \\
$\mathbf{5 5}$ & 6.25 & 6.25 & 3.12 \\
$\mathbf{5 6}$ & & 3.12 & 3.12 \\
\end{tabular}

Ea289: Enterobacter aerogenes 289; PAO1: Pseudomonas aeruginosa ; KPC2ST258 : Klebsiella pneumoniae ST2558

This efficiency was correlated with the inhibition of a dye transport, suggesting an action of these molecules on the activity of drug transporters. Due to their low cytotoxicity these kind of molecules could open the way for the development of new therapeutical strategies.

\section{Conclusion}

During the last decades, the search and commercial development of new antibiotics did not follow the rhythm of emergence of Multidrug resistant bacteria. An alternative to this strategy 
is the finding of active molecules (that we will call antibiotic potentiators or chemosensitizers), preferably with a weak antibiotic activity and that in combination with antibiotics are able to enhance or synergize the antimicrobial activity of the latter. Antibiotic adjuvants can function either by reversing resistance mechanisms in naturally sensitive pathogens or by sensitizing intrinsic resistant strains. Thus, the use of antibiotic adjuvants has two beneficial outcomes: enhancement of the antimicrobial effect and reduction of the occurrence of mutations that results in resistance. In this context and as underlined in this review the search for molecules such as polyamine derivatives which act by membrane depolarization and/or integrity membrane disruption could constitute an efficient alternative since their mechanism of action may significantly reduce the development of resistance. Finally, we can envision that the continuous advances in the development of new and potent high-throughput technologies will definitively allow the discovery of new compounds with antibiotic adjuvant activity which is a less expensive alternative to the problem of Multidrug resistance.

\section{References}

1 O'connell KMG, Hodgkinson JT, Sore HF, Welch M, Salmond GPC, Spring DR. Combating multidrug-resistant bacteria: current strategies for the discovery of novel antibacterials. Angew. Chem. Int. Ed. 52, 10706-10733 (2013).

2 Som A, Navasa N, Percher A, Scott RW, Tew GN, Anguita J. Identification of synthetic host defense peptide mimics that exert dual antimicrobial and antiinflammatory activities. Clin. Vaccine Immunol. 19(11), 1784-1791 (2012).

3 Ralton L, Bestwick CS, Lin PKT. Polyamine analogues and derivatives as potential anticancer agents. Curr. Bioact. Compd. 3, 179-191 (2007).

4 Dela Vega AL, Delcour AH. Polyamines decrease Escherichia coli outer membrane permeability. J. bacteriol. 178(13), 3715-3721 (1996). 
5 Kwon DH, Lu CD. Polyamines induce resistance to cationic peptide, aminoglycoside, and quinolone antibiotics in Pseudomonas aeruginosa PAO1. Antimicrob. Agents Chemother. 50(5), 1615-1622 (2006).

6 Leeuwenhoek, DA. De natise semine genitali animalculis. Philos. Trans. Roy. Soc. 2, 1040-1043 (1677).

7 Samartzidou H, Delcour AH. Excretion of endogenous cadaverine leads to decrease in porin-mediated outer membrane permeability. J. bacteriol. 181(3), 791-798 (1999).

8 Chaturvedi; R, Asim M, Barry DP, Frye JW, Casero RA, Wilson KT. Spermine oxidase is a regulator of macrophage host response to Helicobacter pylori: enhancement of antimicrobial nitric oxide generation by depletion of spermine. Amino acids 46(3), 531-542 (2014).

9 Johnson L, Mulcahy H, Kanevets U, Shi Y, Lewenza S. Surface-localized spermidine protects the Pseudomonas aeruginosa outer membrane from antibiotic treatment and oxidative stress. J. bacteriol. 194(4), 813-826 (2012).

10 Goytia M, Shafer WM. Polyamines can increase resistance of Neisseria gonorrhoeae to mediators of the innate human host defense. Infect. Immun. 78(7), 3187-3195 (2010).

11 Kwon DH, Lu CD. Polyamines increases antibiotic susceptibility in Pseudomonas aeruginosa. Antimicrob. Agents Chemother. 50(5), 1623-1627 (2006).

12 Vaara M, Vaara T. Polycations sensitize enteric bacteria to antibiotics. Antimicrob. Agents Chemother. 24(1), 107-113 (1983).

13 An H, Haly BD, Cook PD. Discovery of novel pyridinopolyamines with potent antimicrobial activity: Deconvolution of mixtures synthesized by solution-phase combinatorial chemistry. J. Med. Chem. 41(5), 706-716 (1998).

14 Magoulas GE, Kostopoulou ON, Garnelis T, Athanassopoulos CM, Kournoutou GG, Leotsinidis M, Dinos GP, Papaioannou D, Kalpaxis DL. Synthesis and antimicrobial activity of chloramphenicol-polyamine conjugates. Bioorg. Med. Chem. 23(13), 31633174 (2015).

15 Reddy VM, Einck L, Andries K, Nacy CA. In vitro interactions between new antitubercular drug candidates SQ109 and TMC207. Antimicrob. Agents Chemother. 57(7), 2840-2846 (2010).

16 Meng Q Luo H, Liu Y, Li W, Zhang W, Yao Q. Synthesis and evaluation of carbamate prodrugs of SQ109 as antituberculosis agents. Bioorg. Med. Chem. Lett. 19, 2808-2810 (2009). 
17 Wu J, Zhang HB, Xu JL, Cox RJ, Simpson TJ, Zhang LH. ${ }^{13}$ C Labeling reveals multiple amination reactions in the biosynthesis of a novel polyketide polyamine antibiotic zeamine from Dickeya zeae. Chem. Commun. 46, 333-335 (2010).

18 Balakrisna R, Wood SJ, Nguyen TB, Miller KA, Kumar EVKS, Datta A, David SA. Structural correlates of antibacterial and membrane-permeabilizing activities in acylpolyamines. Antimicrob. Agents Chemother. 50(3), 852-861 (2006).

19 Moore KS, Wehrli S, Roder H, Rogers M, Forrest JN, McCrimmon D, Zasloff M. Squalamine, an aminosterol antibiotic from the shark. Proc. Natl. Acad. Sci. USA 90,1354-1358 (1993).

20 Shu Y, Jones SR, Kinney WA, Selinsky BS. The synthesis of spermine analogs of the shark aminosterol squalamine. Steroids 67, 291-304 (2002).

21 Tessema TD, Gassler F, Shu Y, Jones S, Selinsky BS. Structure-activity relationships in aminosterol antibiotics: The effect of stereochemistry at the 7-OH group. Bioorg. Med. Chem. Lett. 23, 3377-3381 (2013).

22 Khan SN, Jung YM, Kim BJ, Cho H, Lee J, Kim HS. Synthesis and antimicrobial activity of 7 alpha-amino-23,24-bisnor-5 alpha-cholan-22-ol derivatives. Bioorg. Med. Chem. Lett. 18, 2558-2561 (2008).

23 Khan SN, Kim HS. Synthesis and biological activities of 3-polyamino-5-beta cholane7 alpha, 24 diols. J. Indus. Eng. Chem. 15, 561-565 (2009).

24 Kim HS, Khan SN, Jadhav JR, Jeong JW, Jung K, Kwak JH. A concise synthesis and antimicrobial activities of 3-polyamino-23,24-bisnorcholanes as steroid-polyamine conjugates.Bioorg. Med. Chem. Lett. 21, 3861-3865 (2011).

25 Kikuchi K, Bernard EM, Sadownik A, Regen SL, Armstrong D. Antimicrobial activities of squalamine mimics. Antimicrob. Agents Chemother. 41, 1433-1438 (1997).

26 Loncle C, Salmi C, Letourneux Y, Brunel JM. Synthesis of new 7-aminosterol squalamine analogues with high antimicrobial activities through a stereoselective titanium reductive amination reaction. Tetrahedron 63, 12968-12974 (2007).

27 Salmi C, Loncle C, Vidal N, Letourneux Y, Brunel JM. New stereoselective titanium reductive amination synthesis of 3-amino and polyaminosterol derivatives possessing antimicrobial activities. Eur. J. Med. Chem. 43, 540-547 (2008).

28 Alhanout K, Brunel JM, Raoult D, Rolain JM. In vitro antibacterial activity of aminosterols against multidrug-resistant bacteria from patients with cystic fibrosis. $J$. Antimicrob. Chemother. 64, 810-814 (2009). 
29 Alhanout K, Malesinki S, Vidal N, Peyrot V, Rolain JM., Brunel JM. New insights into the antibacterial mechanism of action of squalamine. J. Antimicrob. Chemother. 17, 3909-3917 (2010).

30 Salmi C, Loncle C, Vidal N, Letourneux Y, Fantini J, Maresca M, Taïeb N, Pagès JM, Brunel JM. Squalamine, an appropriate strategy against the emergence of multidrug resistant gram-negative bacteria? PLoS One 3, e2765 (2008).

31 Djouhri L, Vidal N, Rolain, JM, Brunel JM. Synthesis of new 3,20bispolyaminosteroid squalamine analogues and evaluation of their antimicrobial activities. J. Med. Chem. 54, 7417-7421 (2011).

32 Yasuda K., Ohmizo C., Katsu T. Mode of action of novel polyamines increasing the permeability of bacterial outer membrane. Int. J. Antimicrob. Agents. 24, 67-75 (2004).

33 Lavigne JP, Brunel JM, Chevalier J, Pages JM. Squalamine, an original chemosensitizer to combat antibiotic-resistant Gram-negative bacteria. J. Antimicrob. Chemother. 65, 799-801 (2010).

34 Brunel JM, Lieutaud A, Lome V, Pagès JM, Bolla JM. Polyamino geranic derivatives as new chemosensitizers to combat antibiotic resistant Gram-negative bacteria Bioorg. Med. Chem. 21, 1174-1179 (2013).

35 Pieri C, Borselli D, Di Giorgio C, De Méo M, Bolla JM, Vidal N, Combes S, Brunel, JM. New ianthelliformisamine derivatives as antibiotic enhancers against resistant Gram-negative bacteria. J. Med. Chem. 57, 4263-4272 (2014). 